\title{
The Effect of Organizational Commitment and Perceptions of Organizational Support (POS) on Turnover Intention at PT Aman World Logistics
}

\author{
Silviya Rachmawati, Bayu Airlangga Putra, Ani Wulanndari, Qausya Faviandani \\ Faculty of Economic and Business, Narotama University, Surabaya \\ silviyarachmawati@gmail.com, bayu.airlangga71@gmail.com, \\ ani.wulandari@narotama.ac.id, qausya@narotama.ac.id
}

\begin{abstract}
The problem of this research is about organizational commitment and Organizational Support Perception is partial and together (simultaneously) a significant effect on turnover intention in PT Secure World Logistics. The population of the research is all sixty-three employees of PT Aman World Logistics, with a saturated sample technique. The sample in this research took all sixty-three employees of PT Aman World Logistics. The method of this research is multiple linear regression analysis. Based on the results of the analysis and discussion, it can be concluded that the variable organizational commitment (X1) and perceived organizational support (X2) partially and together (simultaneously) have a significant effect on turnover intention $(\mathrm{Y})$.
\end{abstract}

\section{Keywords :}

Organizational Commitment, Perceived Organizational Support, Turnover Intention

\section{Introduction}

Good human resource management is a must in an organization to be able to compete with other more advanced organizations, but in managing human resources, it is certainly different from managing other resources. It takes an effort to establish a harmonious relationship between employees and the company. Employees are valuable to the company, especially as actors who support the achievement of organizational goals. The existence of employees needs to be managed properly in order to make a positive contribution to the progress of the organization. Conversely, employees will be less enthusiastic about working and eventually resign or leave the workplace (turnover) if employees are not managed properly. PT Aman World Logistics is one of the Marine Cargo Expeditionary (EMKL) companies in Surabaya, founded in 2002s. PT Aman World Logistics continues to develop the quality of its services. It makes the company to be the best EMKL service and competes in price and service.

Table 1.The achievements of Monthly Sales of PT Usaha Utama Bersaudara Surabaya Branch

\begin{tabular}{cccc}
\hline Year & Number of employees & Employees Leave & Percentage \\
\hline 2014 & 88 & 14 & $16 \%$ \\
2015 & 88 & 19 & $21.6 \%$ \\
2016 & 96 & 18 & $18.8 \%$ \\
2017 & 102 & 23 & $22.5 \%$ \\
2018 & 102 & 26 & $25.5 \%$ \\
\hline
\end{tabular}

Source: Processed data (2021)

There are several factors that affect employee performance, namely organizational commitment and Perceptions of Organizational Support.

From the background explanation above the writer formed the title "The Effect of Organizational Commitment and Perceptions of Organizational Support (POS) on Turnover Intention at PT Aman World Logistics." 


\section{JURNAL EKONOMI}

\section{Theoretical Framework}

\subsection{Organizational Commitment}

Organizational commitment is an attitude that reflects the extent to which an individual knows and is tied to an organization, this opinion was conveyed by Griffin (2013), in contrast to Kreitner (2014) defines organizational commitment as the level where one recognizes an organization and is attached to its goals. This is an important work attitude because committed people are expected to show a willingness to work harder to achieve organizational goals and have a greater desire to continue working in a company.

\subsubsection{Organizational Commitment Indicator} namely:

According to Mangkunegara (2013) there are three pillars in creating organizational commitment,

1. There is a feeling of belonging to the organization

2. There is an attachment or excitement to work

3. The importance of belonging

\subsection{Perceived Organizational Support (Perceived Organizational Support)}

According to Robbins (2015) perceived organizational support or perceived organizational support is the level where employees believe the organization appreciates their contribution and cares about their welfare. POS can also be viewed as an organizational commitment to employees. If the organization generally appreciates employee dedication and loyalty as a form of employee commitment to the organization, then employees in general also pay attention to how committed the organization has to them. Awards given by organizations can be considered to provide benefits for employees, such as a feeling of acceptance and recognition, obtaining salaries and promotions, getting various access to information, as well as several other forms of assistance that employees need to be able to carry out their work effectively.

\subsubsection{Indicators Perceived Organizational Support (Perceived Organizational Support)}

According to Farasat (2013), stated that there are 4 dimensions that can increase the organizational support felt by employees, namely:
a. Fairness
b. Support from superiors
c. Organizational rewards
d. Working conditions

\subsection{Turnover Intention}

Judge (2015) expressed his opinion about the meaning of turnover intention, according to him, turnover intention is the tendency or level at which an employee has the possibility to leave the company either voluntarily or not voluntarily due to the lack of attractiveness of the current job and the availability of other job alternatives.

Susiani (2014) states that turnover intention is a feeling that arises from an individual, namely the intention to quit his job voluntarily according to his own choice, whereas (Mobley, 2014) says that turnover intention is the result of an individual evaluation of the continuation of his relationship with the company where he works but has not yet manifested in real action

\subsubsection{Indicators of Turnover Intention}

Mobley (2014) argues that there are three indicators used to measure turnover intention, namely:

a. Thoughts of quitting

b. Intention to quit

c. Intention to search for another job

\section{Research Methods}

\subsection{Population and Sample}

This type of research approach is a quantitative type. On the other hand, the sample is part of the characteristics of the population. The population in the research is all sixty-three employees of PT Aman World Logistics. By using purposive sampling, the sample in this research took all sixty-three employees of PT Aman World Logistics. 


\section{JURNAL EKONOMI}

\subsection{Data Analysis Technique}

The analysis technique used in this research is multiple linear regression analysis, by previously testing the quality of the data obtained using validity and reliability tests. The research is also using the classic assumption deviation test and hypothesis testing.

\subsection{Validity Test}

The data validity test was used to measure the validity of a questionnaire. And a questionnaire can be said to be valid if there is a similarity between the data collected and the data that actually occurs on the object under research (Sugiyono, 2011). The validity test is carried out by comparing the calculated $\mathrm{r}$ value (for each question item can be seen in the corrected item-total correlations column, with $\mathrm{r}_{\text {productmoment }}$ by looking for degree of freedom $(\mathrm{df})=\mathrm{N}-\mathrm{k}$, in this case $\mathrm{N}$ is the number of samples, and $\mathrm{k}$ is the number of independent research variables If $r_{\text {count }}>r$ productmoment, and is positive, then the question (indicator) is said to be valid (Imam Ghozali, 2013 in Simanjuntak, 2013).

\subsection{Reliability Test}

Reliability test is a tool used to measure the questionnaire which is an indicator of a variable or construct. A questionnaire is said to be reliable or reliable if a person's answer to a statement is consistent or stable over time (I Ghozali, 2011). The reliability test that will be used in this research is to use the SPSS facility, namely the Cronbach Alpha statistical test. The result is if a construct or variable is declared reliable if the Cronbach alpha value is> 0.60 (Imam Ghozali 2011 in Syafrizal 2011).

\subsection{Classic Assumption Test}

The classical assumption test is used to ensure that the regression line equation obtained is linear. The classical assumption test conducted is the normality assumption test, heteroskidacity and multicollinearity. The normality test is used to test whether in the regression model, the two variables (free and bound) have a normal distribution or at least or close to normal (Imam. Ghozali, 2005).

Heteroscedasticity test is the purpose of this test is to test whether in the regression model there is an inequality of variance from the residuals of one observation to another. The way to determine whether there is heteroscedasticity is to look at the plot graph. A certain pattern, such as the dots forming a certain pattern (wavy, widened then narrowed) indicates that heteroscedasticity has occurred. A good regression model is one that is homosexual or heteroscedasticity does not occur (Imam Ghozali, 2011).

The multicollinearity test aims to test whether the regression model finds a correlation between the independent variables (Imam Ghozali, 2011). A good regression model should not have a correlation between the independent variables. If there is a correlation, then there is a multicollinearity problem.

Regression analysis is used to draw a line that shows the direction of the relationship between variables and is used to make predictions. In this research, the equation model in multiple linear regression analysis is as follows:

$$
\begin{aligned}
& Y=\alpha+\beta_{1} X_{1}+\beta_{2} X_{2}+\beta_{3} X_{3}+e \\
& \text { Description: } \\
& Y=\text { Turnover intention } \\
& \alpha=\text { Constant coefficient } \\
& \beta 1=\text { Organizational commitment regression coefficient } \\
& \beta 2=\text { Organizational support perception (POS) regression coefficient } \\
& X 1=\text { Organizational commitment } \\
& X 2=\text { Perceived organizational support (POS) } \\
& \mathrm{e}=\text { Estimated error }
\end{aligned}
$$

\section{Findings and Discussions}

In this research, the questionnaires were distributed to 63 respondents of PT Aman World Logistics employees so that primary data. The data obtained with several tests. Since the results expect the research to present accurate data, the first test is a questionnaire test that includes validity and reliability tests. The second test is the classic assumption test which consists of the normality test, multicollinearity test, heteroscedasticity test. The third test is multiple linear regression analysis, and the fourth test is the hypothetical test using the Ftest to determine simultaneously and the t-test to determine partially. The test results are as follows:

\subsection{Validity and Reliability Tests}

Data from the distribution of questionnaires to 63 respondents of PT Aman World Logistics employees can be said to be valid or reliable if the instruments or indicators used in obtaining data are valid or reliable. So 
it is necessary to test the validity and reliability testing. The validity test was done using the Product Moment correlation coefficient method with a significance level of 0.05 , while for the reliability test the Cronbach's alpha method was used.

\subsubsection{Validity Test}

The validity test result was achieved by looking at each questionnaire item's r-count and r-table through data processing in the SPSS program. Each item is said to be valid if r-count> r-table. The results of the validity test in this research are as follows:

\subsubsection{TQM Variable Validity Test Results (X1)}

Table 2.The Results of Validity Test for TQM Variable

\begin{tabular}{cccc}
\hline Item & r-count & r-table & Description \\
\hline $\mathrm{X}_{1.1}$ & 0.655 & 0.2480 & Valid \\
$\mathrm{X}_{1.2}$ & 0.773 & 0.2480 & Valid \\
$\mathrm{X}_{1.3}$ & 0.730 & 0.2480 & Valid \\
$\mathrm{X}_{1.4}$ & 0.769 & 0.2480 & Valid \\
$\mathrm{X}_{1.5}$ & 0.761 & 0.2480 & Valid \\
$\mathrm{X}_{1.6}$ & 0.729 & 0.2480 & Valid \\
\hline
\end{tabular}

Source: primary data processed by SPSS (2021)

The organizational commitment variable consists of six questionnaire items. The correlation of each item has a value of r-count more than r-table, so based on the validity test, it shows that all items on the organizational commitment variable are declared valid and can be used as a research instrument. The r-table value is from the formula $\mathrm{df}=\mathrm{N}-2$ with a 2-way test at a significance level of 0.05 , which is 0.2480 .

\subsubsection{POS Variable Validity Test Results (X2)}

Table 3.The Results of Validity Test for POS Variable

\begin{tabular}{cccc}
\hline Item & r-count & r-table & Description \\
\hline $\mathrm{X}_{2.1}$ & 0.645 & 0.2480 & Valid \\
$\mathrm{X}_{2.2}$ & 0.438 & 0.2480 & Valid \\
$\mathrm{X}_{2.3}$ & 0.508 & 0.2480 & Valid \\
$\mathrm{X}_{2.4}$ & 0.485 & 0.2480 & Valid \\
$\mathrm{X}_{2.5}$ & 0.601 & 0.2480 & Valid \\
$\mathrm{X}_{2.6}$ & 0.528 & 0.2480 & Valid \\
$\mathrm{X}_{2.7}$ & 0.485 & 0.2480 & Valid \\
$\mathrm{X}_{2.8}$ & 0.589 & 0.2480 & Valid \\
\hline
\end{tabular}

Source: primary data processed by SPSS (2021)

The perception of organizational support variable consists of eight questionnaire items. The correlation of each statement item has a value of r-count more than r-table, so based on the validity test all items on the perception of organizational support variable are valid and can be used as a research instrument. The r-table value is from the formula $\mathrm{df}=\mathrm{N}-2$ with a 2 -way test at a significance level of 0.05 , which is 0.2480 . 


\subsubsection{Turnover Intention Variable Validity Test Results (Y)}

Table 4.The Results of Validity Test for Turnover Intention Variable

\begin{tabular}{cccc}
\hline Items & r-count & r-table & Description \\
\hline$Y_{.1}$ & 0.696 & 0.2480 & Valid \\
$Y_{.2}$ & 0.677 & 0.2480 & Valid \\
$Y_{.3}$ & 0.646 & 0.2480 & Valid \\
$Y_{.4}$ & 0.581 & 0.2480 & Valid \\
$Y_{.5}$ & 0.420 & 0.2480 & Valid \\
$Y_{.6}$ & 0.377 & 0.2480 & Valid \\
\hline
\end{tabular}

Source: primary data processed by SPSS (2021)

The turnover intention variable consists of six questionnaire items. The correlation of each item has a calculated r-value more than the r-table, so based on the validity test, all items on the turnover intention variable are valid and can be used as research instruments. The r-table value is from the formula $\mathrm{df}=\mathrm{N}-2$ with a 2 -way test at a significance level of 0.05 , which is 0.2480 .

\subsubsection{Reliability Test}

To test an item's reliability, the researcher used the Cronbach's Alpha analysis technique for each research variable through the SPSS program. These test results can be reliable if Cronbach's Alpha is> 0.6 (Malhotra, Naresh K., 2012). The results of the reliability test of the variables can be seen in the table below:

Table 5.The Results of Reliability Test

\begin{tabular}{cccc}
\hline Variable & Cronbach's Alpha & Criteria & Description \\
\hline $\begin{array}{c}\text { Organizational } \\
\text { Commitment }\left(\mathrm{X}_{1}\right)\end{array}$ & 0.827 & 0.6 & Reliable \\
$\begin{array}{c}\text { Perceived } \\
\text { Organizational } \\
\begin{array}{c}\text { Support }\left(\mathrm{X}_{2}\right) \\
\text { Turnover Intention } \\
(\mathrm{Y})\end{array}\end{array}$ & 0.647 & 0.6 & Reliable \\
\hline
\end{tabular}

Source: primary data processed by SPSS (2021)

Based on table 5, the Cronbach's alpha value of the organizational commitment variable (X1), perceived organizational support (X2), and turnover intention $(\mathrm{Y})$ is more than 0.6 so that it can be concluded that the data is reliable, which means that the questionnaire can be used in the research.

\subsection{Classic Assumption Tests}

\subsubsection{Normality Test}

Normality tests with graphs can be misleading if not done carefully; visually, it looks normal but statistically not, or vice versa, visually abnormal but statistically normal.

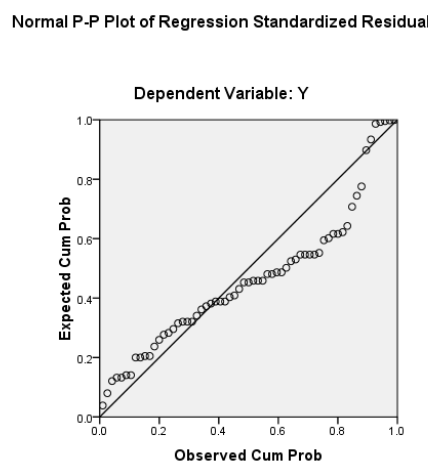

Figure 1. Normality Test Result

Source: primary data processed through SPSS (2021) 


\section{JURNAL EKONOMI}

\subsubsection{Heteroscedasticity Test}

The heteroscedasticity test aims to detect different relevant values from each variant of the independent variable, namely organizational commitment (X1) and perceived organizational support (X2) in the regression model. The heteroscedasticity problem in this research was identified using a scatterplot, namely by plotting standardized predictors with a standardized residual model. If there is no clear pattern and the dots spread above and below the 0 on the $\mathrm{Y}$ axis, there is no heteroscedasticity. The following are the scatterplot results obtained from the SPSS output.



Figure 2. Heteroscedasticity Test Result

Source: primary data processed through SPSS (2021)

The figure above shows that the scatterplot does not form a specific pattern and the points are spread evenly.

\subsubsection{Multicollinearity Test}

The multicollinearity test aims to test whether the regression model found a correlation between the independent variables, namely organizational commitment (X1) and perceived organizational support (X2). Multicollinearity can be seen from the Tolerance and Variance Inflation Factor (VIF) values. If the Tolerance value $<0.1$ or Variance Inflation Factor (VIF) $>10$, multicollinearity occurs. If the Tolerance value $>0.1$ and the Variance Inflation Factor (VIF) value $<10$, multicollinearity does not occur.

Table 6. Multicollinearity Test Result

\begin{tabular}{cccc}
\hline \multirow{2}{*}{ Model } & \multicolumn{2}{c}{ Collinearity Statistics } & Description \\
& Tolerance & VIF & \\
\hline$X_{1}$ & 0,259 & 3,854 & There is no multicollinearity \\
$\mathrm{X}_{2}$ & 0,259 & 3,854 & There is no multicollinearity \\
\hline \multicolumn{4}{c}{ Source: primary data processed through SPSS (2021) }
\end{tabular}

Based on the table above, all variables' tolerance value is more than 0.1 , while the variance inflation factor (VIF) value is less than 10. So it can be concluded that this research data does not experience multicollinearity between independent variables.

\subsubsection{Multiple Linear Regression Analysis}

Regression analysis is used to determine the relationship between the independent variables and the dependent variable. Based on the regression analysis using SPSS, the following results were obtained: 


\section{JURNAL EKONOMI}

Table 7. Multicollinearity Test Result

\begin{tabular}{|c|c|c|c|c|c|c|}
\hline & \multirow[b]{2}{*}{ Model } & \multirow{2}{*}{\multicolumn{3}{|c|}{ 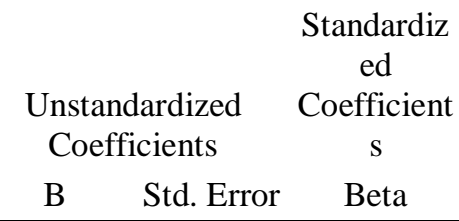 }} & \multirow[b]{2}{*}{$\mathrm{t}$} & \multirow[b]{2}{*}{ Sig. } \\
\hline & & & & & & \\
\hline \multirow[t]{3}{*}{1} & (Constant) & 32.010 & 2.339 & & 13.683 & .000 \\
\hline & $\mathrm{X} 1$ & -.368 & .129 & -.426 & -2.852 & .006 \\
\hline & $\mathrm{X} 2$ & -.350 & .127 & -.412 & -2.761 & .008 \\
\hline
\end{tabular}

\subsection{Hypothesis Testing}

\subsubsection{F-Test (Simultaneous)}

This test determines whether the independent variable, in this case, organizational commitment (X1) and perceived organizational support (X2) together (simultaneously), have a significant effect on the dependent variable, namely turnover intention (Y).

Based on table 8 below, it is known that organizational commitment (X1) and perceived organizational support (X2) simultaneously have a significant effect on the dependent variable, namely turnover intention (Y). It can be seen from the significant value of 0.000 less than alpha 0.05 with an F-count of 56.496 is more than Fcount of 2.76 .

Table 8. F-Test Result

\begin{tabular}{ccccccc}
\hline \multicolumn{1}{c}{ Model } & $\begin{array}{c}\text { Sum of } \\
\text { Squares }\end{array}$ & df & $\begin{array}{c}\text { Mean } \\
\text { Square }\end{array}$ & F & Sig. \\
\hline 1 & $\begin{array}{c}\text { Regr } \\
\text { essio } \\
\mathrm{n}\end{array}$ & 163.291 & 2 & 81.645 & 56.496 & $.000^{\mathrm{a}}$ \\
& & & & & \\
$\begin{array}{r}\text { Resi } \\
\text { dual }\end{array}$ & 86.709 & 60 & 1.445 & & \\
& Total & 250.000 & 62 & & & \\
\hline
\end{tabular}

Source: primary data processed through SPSS (2021)

\subsubsection{T-Test (Partial)}

This test determines whether the independent variable in the regression model partially has a significant relationship to the dependent variable. Based on the results of the t-test with SPSS, which are presented in Table 8 above, it is known that the organizational commitment variable (X1) has a significant effect on turnover intention (Y). It can be proven with a significance value of 0.006 , which is less than 0.05 . Meanwhile, the $\mathrm{t}-$ count of 2.854 more than the t-table of 2,00030. So it can be concluded that the variable organizational commitment has a significant effect on partially turnover intention variables.

The significance value for the organizational commitment variable (X2) is 0.008 , less than 0.05 , and the t-count value of 2.761 is more than the t-table of 2.00030 . So it can be concluded that the organizational communication variable (X2) partially has a significant effect on the turnover intention variable.

\subsection{The Coefficient of Multiple Determination Analysis}

The analysis of the coefficient of multiple determination aims to determine the correlation and relationship between variables of the regression model in this study and measure how close the estimated regression lines are to the actual data. From the R and R2 coefficients, the result is seen. The results of analyzing the multiple correlation co-efficient in this study are in the following table: 
Table 9. The Coefficient of Multiple Determination Analysis Result

\begin{tabular}{ccccc} 
& & \multicolumn{2}{c}{$\mathrm{R}$} & \multicolumn{2}{c}{ Adjusted R Std. Error of } \\
Model & $\mathrm{R}$ & Square & Square & \begin{tabular}{c} 
the Estimate \\
\hline 1
\end{tabular} \\
\hline $808^{\mathrm{a}}$ & .653 & .642 & 1.202 \\
\hline
\end{tabular}

Source: primary data processed through SPSS (2021)

The result shows that an $\mathrm{R}$ of 0.808 indicates that the correlation between turnover intention and organizational commitment variable (X1) and perceived organizational support (X2) is strong because the Rvalue is more than 0.5. From the analysis of the coefficient of multiple determinate with the help of SPSS, it is known that the coefficient of determination of the multiple adjusted $\mathrm{R}$ Square is 0.642 or $64.2 \%$. This value shows that the turnover intention variable's variation is influenced by the organizational commitment variable (X1) and the perception of organizational support (X2). The remaining $35.2 \%$ is related to other variables not examined in this study.

\section{Results of the Study}

Based on the results of the research, the conclusions are as follows:

a) The organizational commitment variable (X1) has a positive and significant effect on turnover intention (Y).

b) The variable perceived organizational support (X2) has a positive and significant effect on turnover intention (Y).

c) The variables organizational commitment (X1) and perceived organizational support (X2) simultaneously have a positive and significant effect on turnover intention (Y).

Some suggestions that can be put for consideration for the company and further research include:

a) From the lowest mean answer to X1. The company must continue to build a discernment for the employees, so they keep prioritizing the interests in working at the company.

b) From the lowest mean answer to X2. The company must continue to build the working atmosphere according to the job descriptions and expected by employees.

c) From the lowest mean answer to Y. The company must continue to build comfort so that employees do not feel like leaving the company

d) For researchers who will conduct further research, this research is expected to be used as a reference, support, guidelines, comparison, and it is hoped that to add other variables that can be used as indicators in further research. There are still variables that researchers have not found that still have a relationship related to purchasing decisions.

\section{References}

Farasat. (2013). Perceived Organizational Support and Deviant Behavior. Journal of Basic and Applied Scientific Research, 3(5).

Ghozali, I. (2011). Aplikasi Analisis Multivariate Dengan Program SPSS. Badan Penerbit Universitas Diponegoro.

Ghozali, Imam. (2005). Aplikasi Analisis Multivariate dengan SPSS.

Ghozali, Imam. (2011). Aplikasi Analisis Multivariate Dengan Program SPSS.

Ghozali, Imam. (2013). Aplikasi Analisis Multivariat dengan Program IBM SPSS. Penerbit Universitas Diponegoro.

Griffin, M. dan. (2013). Perilaku Organisasi. Salemba Empat.

Judge, R. (2015). Perilaku Organisasi (16th ed.). Salemba Empat.

Kreitner, R. dan A. K. (2014). Perilaku Organisasi (9th ed.). Salemba Empat.

Malhotra, Naresh K., and D. F. B. (2012). Marketing Research: An Applied Approach 3rd European Edition.

Mangkunegara. (2013). Manajemen Sumber Daya Manusia Perusahaan. Remaja Rosdakarya.

Mobley, W. (2014). Pergantian Karyawan; Sebab Akibat Dan Pengendaliannya. Gramedia.

Robbins, S. (2015). Perilaku Organisasi. Salemba Empat.

Simanjuntak. (2013). Dampak Otonomi Daerah di Indonesia; Merangkai Sejarah Politik dan Pemerintahan Indonesia. Yayasan Pustaka Obor Indonesia.

Sugiyono. (2011). Metode Penelitian Kuantitatif, Kualitatif dan R\&D.

Susiani, V. (2014). Pengaruh kepuasan kerja dan komitmen pada Turnover intention. E-Jurnal Universitas Udayana. 


\section{JURNAL EKONOMI}

Syafrizal, G. D. (2011). Analisis Pengaruh Kepuasan Kerja terhadap Turnover Intention serta Dampaknya terhadap Kinerja Karyawan. Studi Pada Hotel Horison Semarang.

\section{Biography}

Silviya Rachmawati, is a student at Narotama University, Faculty of Business Economics, majoring in Management. Born in the city of Surabaya, precisely on J1 sampoerna No 6D, November 11, 1997. To get a bachelor's degree, I did my thesis and made this journal. 